\title{
Editorial \\ COVID-19: Measles and Antibiotic Resistance Are a Matter of Concern
}

\author{
Giovanni Di Guardo
}

check for

updates

Citation: Di Guardo, G. COVID-19: Measles and Antibiotic Resistance Are a Matter of Concern. Pathogens 2021, 10, 449. https://doi.org/ 10.3390 / pathogens 10040449

Received: 25 March 2021

Accepted: 7 April 2021

Published: 9 April 2021

Publisher's Note: MDPI stays neutral with regard to jurisdictional claims in published maps and institutional affiliations.

Copyright: (C) 2021 by the author. Licensee MDPI, Basel, Switzerland. This article is an open access article distributed under the terms and conditions of the Creative Commons Attribution (CC BY) license (https:/ / creativecommons.org/licenses/by/ $4.0 /)$.
General Pathology and Veterinary Pathophysiology, Veterinary Medical Faculty of the University of Teramo, Località Piano d'Accio, 64100 Teramo, Italy; gdiguardo@unite.it

Keywords: COVID-19; SARS-CoV-2; measles; measles virus; antibiotic resistance

An interesting Perspective article recently published in the New England Journal of Medicine offers an insightful overview on the benefits provided by the mass vaccination of children against Severe Acute Respiratory Syndrome CoronaVirus-2 (SARS-CoV-2), the betacoronavirus responsible for the dramatic CoronaVirus Disease-2019 (COVID-19) pandemic [1].

To this aim, an elegant parallel is also made with measles, a disease still killing 100,000 people globally each year [2], and with many recent outbreaks affecting unvaccinated children [1]. Noteworthily, measles virus $(\mathrm{MeV})$ is responsible-in humans as well as in experimentally infected macaques - for the partial loss of antibody-based immune memory against previously encountered pathogens (either naturally or following vaccination) [2]. Consequently, the occurrence of a $\mathrm{MeV}$ infection's outbreak among COVID-19-vaccinated children and/or adults could have very negative effects, especially when an adequate "herd immunity" level should be reached.

Such an alarming scenario is made even more scary by the SARS-CoV-2 variants (so-called "variants of concern", VOC) circulating in many Countries, both European (including Italy) and non-European, such as the "English" (alias "B.1.1.7"), "South African" (alias "B.1.351"), "Brazilian" (alias "P.1"), "Nigerian" (alias "B.1.525") and "Mexican" (alias "B.1.1.222") VOC, which were preceded by the one known as "cluster 5" (characterized by the "Y453F" mutation within the "receptor-binding domain" of SARS-CoV-2 spike protein), found during late spring and early summer of 2020 in mink farms in the Netherlands and Denmark [3]. Indeed, concern exists that the aforementioned VOC, with special reference to the South African and Brazilian ones, could escape-at least partially-the immunity conferred by a previous infection, as well as by the currently available anti-SARS-CoV-2 vaccines $[4,5]$.

Many comparisons have also been made, in the biomedical literature and elsewhere, between COVID-19 and "Spanish flu", although no antibiotics against the frequently occurring bacterial superinfections were available when the "1918 influenza pandemic" took place. Indeed, penicillin - the first antibiotic in history-was discovered only in 1928 by Alexander Fleming, who, in 1945-17 years later-was awarded with the Nobel Prize by the Royal Swedish Academy of Sciences for his literally revolutionary discovery. As a consequence, the fact that no antibiotics were available by the time Spanish flu occurred, objectively makes any parallel between the two pandemics implausible, if not even impossible [6].

Notwithstanding the above, the role of antibiotic-resistant bacteria (ARB) in the clinicopathological evolution and outcome of COVID-19 among hospitalized patients of all ages has not received, thus far, the attention such a crucial issue would deserve.

A recent report from the World Health Organization (WHO) states, in fact, that "of those taking antibiotics, 79-96\% reported not having been infected with COVID-19, but were taking antibiotics inappropriately, believing they would prevent infection. Evidence 
indicates that up to $15 \%$ of severely affected COVID-19 patients develop bacterial coinfection and could need antibiotics, whereas $75 \%$ actually receive them" [7].

The critical relevance of this issue is well exemplified by the commonly documented involvement of ARB in severe nosocomial infections [8], as clearly shown by the 700,000 deaths caused in 2019 by ARB worldwide, 33,000 of which occurred across the European Union (EU), with 10,000 of them having been reported in Italy, the country with the highest toll in human lives inside EU due to ARB-associated/related infections [9].

Funding: This research received no external funding.

Conflicts of Interest: The author declares no conflict of interest.

\section{References}

1. Klass, P.; Ratner, A.J. Vaccinating children against COVID-19-The lessons of measles. N. Engl. J. Med. 2021, 384, 589-591. [CrossRef] [PubMed]

2. Mina, M.J.; Kula, T.; Leng, Y.; Li, M.; de Vries, R.D.; Knip, M.; Siljander, H.; Rewers, M.; Choy, D.F.; Wilson, M.S.; et al. Measles virus infection diminishes preexisting antibodies that offer protection from other pathogens. Science 2019, 366, 599-606. [CrossRef] [PubMed]

3. European Center for Disease Prevention and Control (ECDC). Detection of New SARS-CoV-2 Variants Related to Mink. 12 November 2020. Available online: https:/ / www.ecdc.europa.eu/sites/default/files/documents/RRA-SARS-CoV-2-in-mink-12 -nov-2020.pdf (accessed on 22 March 2021).

4. Callaway, E.; Ledford, H. How to redesign COVID vaccines so they protect against variants. Nature 2021, 590, 15-16. [CrossRef] [PubMed]

5. Lauring, A.S.; Hodcroft, E.B. Genetic variants of SARS-CoV-2: What do they mean? JAMA 2021, 325, 529-531. [CrossRef] [PubMed]

6. Di Guardo, G. COVID-19 and Spanish flu, 100 Years Make the Difference! (Rapid Response/Letter to the Editor). BMJ. 2020. Available online: https:/ / www.bmj.com/content/370/bmj.m3074/rr-0 (accessed on 22 March 2021).

7. World Health Organization (WHO). Regional Office for Europe. Preventing the COVID-19 pandemic from causing an antibiotic resistance catastrophe. In WHO Reports; WHO: Geneva, Switzerland, 2020.

8. Denys, G.A.; Relich, R.F. Antibiotic resistance in nosocomial respiratory infections. Clin. Lab. Med. 2014, 34, 257-270. [CrossRef] [PubMed]

9. Bellino, S.; Iacchini, S.; Monaco, M.; Del Grosso, M.; Camilli, R.; Errico, G.; D'Ancona, F.P.; Pantosti, A.; Pezzotti, P.; Maraglino, F.; et al. AR-ISS: National Antibiotic Resistance Surveillance Data 2019 (Report); Italian National Institute of Health (ISS): Rome, Italy, 2020; pp. 1-20. 